\title{
Definitions and Contexts of Intercultural Dialogue in European Policy Documents
}

\begin{abstract}
In this chapter, we analyse how the concept of intercultural dialogue is both explicitly and implicitly used in European education policy documents. First, we explore how the concept is explicitly dealt with in the documents and how its meanings are produced in relation to other concepts and terms, such as culture, cultural heritage, identity, inclusion, empathy, tolerance, multiculturalism, citizenship, participation, and social responsibility. We pay special attention to the values and ideals conveyed by the education policy documents in general and these concepts in particular. Second, we discuss the thematic overlap of these concepts and how different concepts, terms, and conceptual expressions can be used interchangeably in policy documents. These examples illuminate the conceptual network and semantics of the concept of intercultural dialogue.
\end{abstract}

Keywords Culture $\bullet$ Cultural heritage $\bullet$ Identity $\bullet$ Inclusion $\bullet$ Tolerance • Intercultural

The Council of Europe and European Union seek to impact on various social, societal, cultural, and economic issues in European societies through their education policy documents. Many of these documents in our data explicitly address intercultural dialogue, but its core aims and ideas are also often implicitly dealt with by referring to matters such as the

(C) The Author(s) 2020

T. Lähdesmäki et al., Intercultural Dialogue in the European

Education Policies, https://doi.org/10.1007/978-3-030-41517-4_3 
development of mutual understanding between people with different backgrounds or to the promotion of respect for difference. This kind of implicit ethos of intercultural dialogue can be found in documents written before the concept itself was established and explicitly included in the policy discourses of both these actors.

We start our analysis by exploring how the concept of intercultural dialogue, as well as the term 'intercultural' as a description of the relationship between different cultures, is explicitly used in our data, and what kinds of meanings they include. When looking at the explicit occurrences in the 67 documents we analysed, the concept of intercultural dialogue is not used very often. It appears explicitly in the European Union's documents 18 times and in the Council of Europe's documents 21 times, a total of 39 mentions. Implicitly and in different variations of the term 'intercultural' it, however, appears significantly more often.

Within the European Union's documents, intercultural dialogue is most often mentioned in the Commission's communication entitled Multilingualism: an Asset for Europe and a Shared Commitment (CofEC 2008). It explicitly occurs 13 times and is also referred to implicitly via similar terms, such as 'intercultural skills' (five times), 'intercultural competences' (once), 'dialogue between cultures' (once), and 'dialogue and mutual respect' (once). The communication was created in 2008 when the Union was celebrating the European Year of Intercultural Dialogue and it dates some months after the Council of Europe launched its White Paper on Intercultural Dialogue. In this document, intercultural dialogue is mostly understood as communication with people from varied cultural and linguistic backgrounds. The other European Union documents in which the concept of intercultural dialogue explicitly appears are as follows: twice in the Commission's Conclusions on a Strategic Framework for European Cooperation in Education and Training (CofEU 2009a); once in the European Parliament's and Council's Regulation on Establishing Erasmus+: the Union Programme for Education, Training, Youth and Sport (EP and CofEU 2013); once in the conclusions of the Commission and member states' governments on Promoting Creativity and Innovation through Education and Training (CofEU \& RofGofMS 2008); and once in the Council's and the Commission's Report on Implementing the Strategic Framework for European Cooperation in Education and Training (CofEU \& EC 2015). In these documents, intercultural dialogue is not defined or explained but gets its meanings through other concepts and terms related to the description of policy goals. As the 
titles of these documents indicate, they focus on transnational cooperation in education, increasing opportunities for European young people, and the employment potential of the Union as a whole.

Within the Council of Europe's data, intercultural dialogue has the highest occurrence in the recommendation on intercultural dialogue in history teaching (CofE 201 lb) (ten mentions of 'intercultural dialogue', one of 'dialogue between cultures', one of 'dialogue', and one of 'interfaith dialogue'). This frequency reflects the focus of the document, which is made explicit in its title. The Council's Charter on Education for Democratic Citizenship and Human Rights Education also refers to intercultural dialogue five times (CofE 2010), and the recommendation on integrating and educating young people from a migrant background (CofE 2018), which draws together extracts from various conventions, recommendations, resolutions, and reports, mentions it twice, as does its Recommendation on Ensuring Quality Education (CofE 2012a). Intercultural dialogue is not further defined in these documents, but policies of inclusion and encountering the 'other' form the semantical context for the concept. All these documents were created some years after the White Paper was published.

The term 'intercultural' appears 55 times in the European Union's documents and 69 times in the Council of Europe's documents in various configurations, ranging from intercultural dialogue to intercultural skills and intercultural communication. 'Dialogue', in turn, is used 57 times in the European Union's documents and 40 times in the Council of Europe's documents. The Council document with most occurrences of these two terms is the compilation document on the education and integration of migrant children (CofE 2018). This document mentions 'intercultural' 16 times but 'dialogue' only twice, which points to the fact that 'intercultural' is not only related to dialogue but also seen as a specific skill or competence. 'Dialogue' alone appears most often in the Council of Europe's Charter on Education for Democratic Citizenship and Human Rights Education (CofE 2010). As stated before, in the European Union documents the term 'intercultural' appears most often in the context of multilingualism. Besides dialogue, the Commission communication on multilingualism (CofEC 2008) refers to intercultural skills and competences.

The thematic contexts in which intercultural dialogue is most often discussed in our data thus include multilingualism, history teaching, and immigration. The documents dealing with these themes suggest that 
intercultural dialogue address cultural, linguistic, ethnic, religious, social, and national differences.

Instead of offering explicit definitions, most of the documents in our data simply use the concept of intercultural dialogue in connection to a frequently recurring set of values (such as tolerance, equality, and respect), skills (such as language skills), and groups of people (such as immigrants or people with migrant background). In the Council of Europe's documents, intercultural dialogue is often simply mentioned with reference to the White Paper on the subject or the European Year of Intercultural Dialogue, celebrated in 2008. The Council of Europe's Recommendation on Intercultural Dialogue and the Image of the Other in History Teaching, for example, encourages continuing "the activities of reflecting on and, where appropriate, reforming history teaching in order to create optimum conditions for development of intercultural dialogue founded on tolerance, heedfulness of others, dialogue and training as a responsible citizen capable of personal thought, critical analysis and research" (CofE 201 lb, 3 ). According to this recommendation, history teaching, "in association with other disciplines", should focus on "fostering the preconditions for productive intercultural dialogue, namely promotion of the common values and references such as the fundamental rights needed for dialogue to be established on a sound basis, as specified in the White Paper" (CofE $2011 \mathrm{~b}, 5)$. As these quotations indicate, common values and fundamental rights are depicted as the "preconditions" for cultural dialogue, which itself is described as being "founded on" tolerance and training in dialogical skills such as critical analysis. The explicit definition of intercultural dialogue is, however, missing.

The European Union documents also connect intercultural dialogue to common values such as tolerance, diversity, inclusion, integration, and belonging. The Council of the European Union's Conclusions on Reducing Early School Leaving and Promoting Success in Schools, for example, state that

[i]n our increasingly diverse societies, there is an urgent need for inclusive and coordinated responses from both educational and non-educational stakeholders which are aimed at promoting common values such as tolerance, mutual respect, equal opportunities and non-discrimination, as well as fostering social integration, intercultural understanding and a sense of belonging. (CofEU 2015c, 37) 
In the Commission's communication on multilingualism (CofEC 2008), half of the mentions of 'intercultural dialogue' are simply in subheadings, the table of contents, and references to activities such as the European Year of Intercultural Dialogue. The concept thus vaguely frames various activities, aims, and contents discussed in different sections of the document as intercultural dialogue. When mentioned in the actual body text (CofEC 2008, 2, 3, 5, 6), it usually appears with the concept of social cohesion and is connected to the concepts of (linguistic) diversity, identity, shared inheritance (implicitly invoking the idea of cultural heritage), and culture (as the plural form cultures). It appears in sentences like this: "A successful multilingualism policy can strengthen life chances of citizens: it may increase their employability, facilitate access to services and rights and contribute to solidarity through enhanced intercultural dialogue and social cohesion" (CofEC 2008, 3). Here, intercultural dialogue is discussed in the context of enhancing employment, solidarity, and citizens' rights.

As the previous quotation indicates, the European education policy documents explicitly connect intercultural dialogue to education and skill development. For example, in a Joint Report of the Council of the European Union and the Commission on the Implementation of the Strategic Framework for European Cooperation in Education and Training (CofEU \& EC 2015), intercultural dialogue is only mentioned once, while intercultural skills appear once and intercultural competences three times. These terms are used in the documents almost interchangeably. The Council of Europe's Recommendation on Ensuring Quality Education states that "education must enable pupils and students to develop proficiency in intercultural dialogue" (CofE 2012a, 2). The capacity for intercultural dialogue is, thus, cast as a competence or skill acquired through both formal and informal education-often in the context of lifelong learning.

In the data, informal education includes the work of national and international non-governmental organizations, as well as the contributions of information technology to everyday life. The Commission's communication on multilingualism, for instance, states that the media "have great potential to promote intercultural dialogue by conveying a more complex presentation of our society, allowing for many different voices"-hence the media can "be a great source of informal language learning through 'edutainment' and subtitled films" (CofEC 2008, 12). The same document states that " $[\mathrm{m}]$ ultilingual companies prove how linguistic diversity 
and investing in language and intercultural skills can be turned into a real asset for prosperity and a benefit for all" (CofEC 2008, 7). Here, the 'intercultural' in informal education is related to linguistic diversity, language learning, and learning from 'different voices' raised in the media.

\section{Core Concepts Used to Give Meaning to Intercultural Dialogue}

Since some concepts, such as culture, cultural heritage, and common values, as well as certain attitudes, such as empathy and tolerance, repeatedly come up in theoretical discussions and research on intercultural dialogue, we traced their uses and contexts in our data. We also broadened our analysis to concepts that are closely connected to the semantics of intercultural dialogue, such as identity, inclusion, multiculturalism, citizenship, participation, and social responsibility. All these concepts carry their own definitional ambiguities in both the theoretical literature and policy discourses. Hence, it is imperative that these ambiguities are considered and contextualized before exploring how they are used to construct the idea of intercultural dialogue in the education policies under scrutiny. In this section, we have clustered these concepts into three interrelated groups.

\section{Culture, Multiculturalism, and Cultural Values}

Culture can be defined as having material, social, and subjective components. Physical artefacts, institutions, shared knowledge, beliefs, attitudes, memories, values, and practices all contribute to its formation. Furthermore, social groups of many sizes may have their own distinctive cultures, which means that individuals belong to and participate in many different cultures simultaneously, be these related to nationality, ethnicity, neighbourhood, language, religion, generational ties, or particular organizational, occupational, or vocational groups, to name but a few. The cultural categories according to which interculturalism is defined may be based on perceptions of similarities and differences that shift attention from the interpersonal to the intercultural. These perceived similarities and differences also include styles or habitus related to gender, social class, and sexual orientation (Barrett 2013, 150-152). 
The European Union and the Council of Europe share an explicit aim to promote culture, identity, and values described and defined as European in their policy discourses. The cultural component has been included in both actors' interests from their inception. Although the European Union was initially built on economic and political cooperation, its very founding figures expected that cultural and social integration in Europe emerges as a spillover effect of successful cooperation in other policy fields (e.g. Rosamond 2000; Shore 2006; Sassatelli 2006; Näss 2009). In some views, culture has been considered as one of the underlying ideas that have even motivated the creation and building of the European Community and, later, the Union (Rosamond 2000; Sassatelli 2006; Näss 2009). Besides the culture-related interests during the early decades of European integration, cultural policy itself has become increasingly central to the European Union during the 2000s (e.g. Sassatelli 2009; Näss 2010; O'Callaghan 2011; Lähdesmäki 2012). Culture has been described as the third and the most recent 'wave' of European integration process (Karlsson 2010; Jarausch 2010; Lähdesmäki 2016a, 1; Troitino 2013, xi-xii) and perceived as the Union's “symbolic and poetic dimension” (Banús 2015; Lähdesmäki 2016a) as it offers an instrument and arena to narrate and represent (a wish for) unity, diverse but also shared cultural features, and common values and heritage in Europe.

The discursive prevalence of culture can be easily deciphered in the education policies of both organizations. They frequently refer to culture in our data (the European Union 108 times, of which 22 in the plural 'cultures', and the Council of Europe 44 times, of which 15 times in the plural). Both also refer to different cultural aspects (European Union 91 times/Council of Europe 185), especially in the intercultural sense (European Union 55/Council of Europe 69). The term intercultural is more prominent in the data than multicultural (124 mentions of 'intercultural' and only 14 mentions of 'multicultural'). This reflects the temporal emphasis of the data: all but six of the documents were published after the turn of the millennium, and half of them after 2008, the year of publication of the White Paper that positioned intercultural dialogue as a solution to the alleged failure of multiculturalism policies.

As the notions of multiculturalism and interculturalism demonstrate, the strengthened discourse on culture within Europe-building policiesthat the documents in our data also represent-is largely used as a tool for diversity policies and politics. In some academic studies, the prominence of culture in policy discourses has been explored (and criticized) as a move 
that has merely replaced the by now invalidated concept of 'race', and the politically charged concept of 'nationality', in the framing of difference (Cronin 2002, 313; Lentin and Titley 2012). In European cultural policies, the definition of culture has been interpreted as following an anthropological view that emphasizes shared values and cultural production and practices as underlying elements of all human behaviour, and sees culture as "a key arena in which contestations over identities and rights are played out" (Cronin 2002, 309). Although culture (and cultural consumption) is often framed in European cultural policies in terms of belonging, it nevertheless often excludes various groups of marginalized or dispossessed people (e.g. Cronin 2002, 317).

Following the interest in culturalization of European integration, the ideal of unity within diversity, repeated again and again in European policy documents, became understood as arising from embracing a set of 'common' (cultural/culturalized) values, such as democracy and human rights, or valuing certain freedoms, such as gender equality, freedom of speech, and individualism (de Leeuw and van Wichelen 2012, 198). In this discourse, differences in ways of life are considered assets as long as they do not conflict with these 'common' values and freedoms. De Leeuw and van Wichelen (2012) have noted how these values and freedoms mirror Western European ideals of secular liberalism and exclude, for example, conservative religiousness from the sphere of Europeanness. While embracing unity, the value discourse simultaneously creates cultural others, such as Muslim immigrants. This exclusive discourse may also be detected within the East-West divide of the European Union. As Jones and Subotic $(2011,543)$ note in their analysis of the political aspects of the Eurovision song contest, "the process of Europeanization is fundamentally a process of political imagination". In this context, "European states with uncertain or transitional identities on the European 'periphery' use performative symbols, such as carnivals, festivals or cultural events" (Jones and Subotic 2011, 542), to create an image or illusion of shared beliefs in Europe, at the same time expressing their own beliefs and identities, which may conflict with the European values of tolerance, for instance in relation to gender and sexual minorities. This performative process of conflicting values can, according to Jones and Subotic (2011), be interpreted as a struggle for power and equality in the European sphere. Thus culture as a marker of shared European values may be used as an indicator of difference, like race, ethnicity, and nationality. The line 
between similarity and difference is drawn according to sharing or dissociating from liberal secular values.

In the European education policies, the 'fundamental European values' are described as encompassing tolerance, mutual understanding, human rights, and democratic values (CofE 2001, 2, 4, 5, 8, 15). 'Common European values' are stated to include freedom, tolerance, and non-discrimination (e.g. CofEU 2015a, 2, 2n6, c, 36; 2016, 5nl; CofEU \& EC 2015, 25n2; CofEU \& RofGofMS 2016, ln4). The documents also discuss ethical values that prevent corruption (CofE 2000, 1, 2) and social values shared by the European social area represented by the Council of Europe's contracting parties (CofE 2015, 445). The Council of the European Union's conclusions on Developing Media Literacy and Critical Thinking through Education and Training (CofEU 2016) explicitly refer to common values listed in the current treaty of the European Union, the Treaty of Lisbon (2008). The conclusions emphasize how "the Union is founded on the values of respect for human dignity, freedom, democracy, equality, the rule of law and respect for human rights, including the rights of persons belonging to minorities" (CofEU 2016, 5). Here, the references to minorities and equality also evoke the idea of diversity.

\section{Tolerance, Empathy, and Identity}

The Council of Europe and the European Union define their common or fundamental values in their education policies in a way that reflects how the values involved in intercultural competencies are defined in scholarly literature on interculturalism. Barrett $(2013,153)$, for example, breaks down the values involved in intercultural competence into valuing cultural diversity and valuing pluralism of perspectives and practices. In this valuing, the idea and practice of tolerance becomes important. As seen above, tolerance is both explicitly and implicitly one of the core values presented in the data as a component of 'Europeanness' and European citizenship. In the European Union documents, the shared 'Europeanness' of values is depicted as including "cultural, religious and linguistic diversity, [-] openness towards other cultures, tolerance and acceptance of others" (CofEC 2005, 2-3). The same pages state that "respect for linguistic diversity is a core value of the European Union". Tolerance, diversity, and an open-minded or open attitude towards other cultures and people, thus, form an interrelated triad of values defining 'Europeanness' in the data. 
Openness implicitly invokes the idea of intercultural dialogue, since dialogue requires openness towards other people's points of view.

Scholars have noted how tolerance is a "controversial, multifaceted and complex concept" (Isac et al. 2018a, 128) that evokes both positive and negative meanings (DIALLS 2018). If it is understood as a willingness to put up with objectionable ideas and groups (Sniderman et al. 1989; Mutz 2002), it encompasses negative attitudes towards difference, including prejudice and intolerance (Isac et al. 2018b). In a positive sense, however, tolerance denotes the willingness to extend "freedoms to those whose ideas one rejects, whatever these might be" (Sullivan et al. 1979, 784).

The UNESCO definition of tolerance builds on the positive stance as it speaks of respect, acceptance, openness, harmony, and recognizing others' freedoms:

Tolerance is respect, acceptance and appreciation of the rich diversity of our world's cultures, our forms of expression and ways of being human. It is fostered by knowledge, openness, communication, and freedom of thought, conscience and belief. Tolerance is harmony in difference [-]. Tolerance is, above all, an active attitude prompted by recognition of the universal human rights and fundamental freedoms of others. (UNESCO 1995, 5)

Yet, as tolerance is explicitly related to diversity and difference in European cultural and education policies, diversity and difference are seen in them both as an asset and as a problem. The double-sidedness of tolerance is exemplified by the fact that the word 'tolerance' occurs seven times in the Council of Europe's documents, while 'intolerance' appears nine times. These documents use the term 'tolerant' three times and 'intolerant' once. Tolerance is, thus, often addressed via references to aspirations and projects combating intolerance.

If acceptance includes dealing with differences that one is opposed to, promoting acceptance encompasses an emotional element related not only to values but also to affective structures (related, for example, to beliefs and ideals) that may be difficult to define. In our analysis, we have sought to complement the exploration of tolerance by paying attention to references to empathy. As stated in the introductory chapter, empathy is commonly depicted as a skill that is foundational for intercultural dialogue (Houghton 2012, 97-100; Barrett 2013, 26; Cantle 2013, 80). In studies of interculturalism and intercultural dialogue, tolerance and empathy are often singled out as necessary features of intercultural competence. The 
European education policies, however, rarely address empathy. In the European Union documents, empathy occurs explicitly only once: it is mentioned as one of the key skills related to the social and civic competences of lifelong learning (EP \& CofEU 2006, 17). In the Council of Europe documents, 'empathy' is mentioned twice: it is brought forth in relation to disability and "others who are different" or have unequal opportunities. Both mentions are in the document Democracy and Human Rights Start with Us, in an excerpt that feels like a side comment, pointing to the human rights education manuals Compasito and Compass, which deal with empathy education (CofE 2012b, 31, 32). The word 'empathic' is used only once in the document on intercultural dialogue and the image of the other in history teaching. The appendix to this document on "how to live together" in post-conflict situations notes that, in such contexts, history teaching should "contribute to the necessary processes of empathic responsiveness to others" (CofE 2011b, 6).

While empathy is rarely referred to explicitly in our data, calls for respect, and reconciliation are present in both organizations' education policies. Implicitly, empathy may also be linked to ideas like solidarity, social cohesion, and emotional care as is done in the Commission's communication on multilingualism, which states that multiculturalism contributes "to solidarity through enhanced intercultural dialogue and social cohesion" (CofEC 2008, 3). Moreover, the idea of empathy can be implicitly read into the concept of mutual understanding, which is a more common term in the education policies of both the European Union and the Council of Europe.

Identities form key features of difference, and difference can be understood as the key point of cultural negotiation in dialogic processes (Ganesh and Holmes 2011,82). Yet, our analysis revealed that identity was, next to empathy and tolerance, one of the less used concepts in the European education policies. In the data, the Council of Europe mentioned it only 8 times (of which 3 in the plural form 'identities') and the European Union referred to it 32 times (of which 5 in the plural). The contexts in which identity was referred to also varied broadly from references to national and European identities to migrants' identities, learners' identities, and protecting the identities of whistle-blowers (CofE 2001, 4, 2011 b , 1, 2014a, 3 , b , 3, 2018, 21). The concept of identity was also brought up in relation to language issues, cultural heritage, diversity of cultures, and the identity-shaping aspects of sport (CofEC 2005, 8, 2008, 3; CofEU 2014). In the European Union documents, identity was rarely 
related to cultural identity but was instead used to refer, for example, to the identity of institutes or executive agencies, or to discuss the identification of people more generally-which explains the relatively high number of explicit occurrences.

What is relevant for our analysis here, however, is that identity was explicitly phrased as cultural identity in the context of immigration and integration (CofEU 2009b, 7; EP \& CofEU 2006, 17; CofE 2018, 21) and nationality (CofE 2001, 4; EP \& CofEU 2006, 17). It was also addressed in the context of lifelong learning (EP \& CofEU 2006, 17) and learners' identities in general (CofE 2014a, 3). In the data, identity was articulated thrice as European identity, implying a shared European cultural identity (EP \& CofEU 2006, 17, 2013, 53; CofE 2011b, 1). In the documents, national cultural identity and European identity could also be explicitly connected, such as in the definition of social and civic competences that include " $[\mathrm{u}]$ nderstanding the multi-cultural and socio-economic dimensions of European societies and how national cultural identity interacts with the European identity" (EP \& CofEU 2006, 17). Identity formations in the documents, thus, ranged from broad collective identities to personal understandings of the self.

\section{Inclusion and Heritage}

According to researchers such as de Leeuw and van Wichelen (2012), cultural alignment may become a ticket to inclusion. In the European Union's education policy documents, the concept of inclusion (a total of 55 mentions) is relegated to various contexts, such as socio-economic development (CofEU \& RofGofMS 2016, 2), social inclusion and employment (EC 2017, 2; EP \& CofEU 2013, 57; CofEU 2015b), and active citizenship (e.g. EC 2010, 8; EP \& CofEU 2013, 57, 59; CofEU \& EC 2015, 25-26; CofEU 2015b). It is also implicitly discussed through the prevention of (social) exclusion (e.g. EC 2010, 8) and discrimination (e.g. CofE 1997, 5; CofEU 2009b). In the Council of Europe's documents inclusion (a total of 18 mentions) is commonly discussed through the concept of integration (a total of 121 mentions, including forms such as 'integrate' and 'integrating') and contextually related above all to the integration of migrants and their children into European societies. The European Convention on the Legal Status of Migrant Workers, for example, speaks of providing migrant workers with the "right to admission" (CofE 1997, 2) and "access to higher education" (CofE 1997, 6), and the 
recommendation on validating migrants' skills (CofE 201 la, 1-2) speaks of national integration policies contributing to greater unity between the member states. In the context of immigration, integration is, furthermore, defined as "an interactive process based upon mutual willingness to adapt by both migrants and the receiving society" (CofE 2008, 1). Here, inclusion (a disposition often assigned to the 'tolerant' receiving populace) largely becomes reconceptualized as integration, a two-way process that places considerably more weight on the adaptive participation of the immigrant. Scholars such as de Leeuw and van Wichelen $(2012,198)$ have discussed this burden of adaptation by analysing the Dutch integration exam as a technique of governmentality, directed above all at Muslim immigrants.

In general, inclusion seems to be a 'softer' term than integration in our data, used more in educational contexts (although also e.g. in political contexts referring to social inclusion), while integration seems to be a 'harder' political concept, used with reference to European integration and creating unified societies. It is, thus, often applied when discussing immigrants and their integration into European societies. Both concepts are related to discussions about how to approach cultural backgrounds or heritages that differ from those of a majority that forms a norm in the society.

The concept of 'cultural heritage', in this particular form, appears in the documents a total of eight times: three times in those of the European Union and five times in those of the Council of Europe. However, it occurs implicitly in numerous other forms such as plain heritage; shared inheritance; (our) common cultural background; heritage language; heritage culture; EU heritage; Europe's rich heritage; public and private heritage; architectural heritage; common (historical) heritage; shared ideals and principles; university heritage; academic heritage; shared heritage; cultural and linguistic heritage; and a student's heritage. These implicit references to cultural heritage make the concept altogether more common than the explicit numbers imply. In the European Union documents, cultural heritage is discussed in contexts such as linguistic diversity (CofEC 2008) and migration (CofEU 2009b) and mostly framed as European either implicitly or explicitly (e.g. CofEC 2008, 4; EP \& CofEU 2013, $53)$. In the Council of Europe's education policies, the concept is used most often in the Recommendation on History Teaching in the Twentyfirst Century Europe (CofE 2001), where it is mentioned ten times in its different forms (five as "cultural heritage", as mentioned above). In the 
other documents, heritage is mostly expressed in the context of "common heritage" of the Council of Europe's members. This common heritage is defined as the shared "ideals and principles" of the member countries (e.g. CofE 1954, 1, 1977, 1, 2014b, 1). In the 2001 recommendation on history teaching, heritage is also explicitly linked to identity and citizenship through statements, such as asserting that history teaching should "enable European citizens to enhance their own individual and collective identity through knowledge of their common historical heritage in its local, regional, national, European and global dimensions" (CofE 2001, 5). This statement indicates that heritage can also be perceived in the policy language as multilayered, simultaneously including different scalar meanings.

The meanings of cultural heritage in the data are created with reference to the political and societal principles and ideals of secular liberalism promoted by both European organizations. In particular, 'common' or 'shared' values are turned into heritage in policy discourses that seek to appeal to the unity of these organizations and European societies more broadly (Lähdesmäki 2016b). In their immigration policies, the integration of immigrants into European societies can be dealt with as integration of immigrants to these values and principles - and, thus, to European cultural heritage. Some scholars have even seen potential here for a discriminative discourse: setting liberal secular values of (Western) European countries against (Muslim) immigrants perceived as coming from intolerant religious cultural backgrounds (Lentin and Titley 2012, 134).

\section{Conceptual Overlaps and Interchangeable Concepts}

The analysis of European education policy documents indicated that some of the concepts that are commonly discussed in scholarly literature on intercultural dialogue-which is why we chose to examine them more closely-occurred often in our data, while others were less frequently used. Moreover, some of the concepts turned out to have less significant content for illuminating the idea and practices of intercultural dialogue. For instance, citizenship and participation were commonly addressed in the data without a direct link or in contexts irrelevant to intercultural dialogue and did not feature prominently in the 'dense' extracts that explicitly and/or implicitly addressed intercultural dialogue (that are analysed in the next chapter). Other concepts, such as (cultural) identity, tolerance, 
and empathy, were rarely used in our data, although they play an important role in the idea and practices of intercultural dialogue.

The European education policy documents in our data often seemed to deal with the idea and practices of intercultural dialogue without explicitly referring to the concept as such. Similarly, the core concepts that we chose to examine more closely were often addressed through various other concepts, terms, and expressions. Inclusion, for example, was mostly dealt with in terms of 'integration' in the Council of Europe documents and as social inclusion in the European Union documents. In some instances, inclusion was also referred to in (value) statements that spoke of cohesion, unity, understanding, recognition, admission, access, approval, accession (in relation to working against discrimination), non-discrimination, and equality. Empathy was also rarely used explicitly, but addressed by calling for respect, solidarity, mutual understanding, and reconciliation. Tolerance, in turn, was often referred to via references to aspirations and projects combating intolerance. Multiculturalism was likewise hardly mentioned as such in the data, but multicultural circumstances were referred to via terms such as plurilingualism and cultural diversity. Social responsibility was not mentioned explicitly in the documents, but the concept appeared once as 'socially responsible' when referring to the "the need to understand and use language in a positive and socially responsible manner". Socially responsible use of language was included in a "positive attitude" that requires "a disposition to critical and constructive dialogue [-] and an interest in interaction with others" (EP \& CofEU 2006, 14), thus echoing the ideals of intercultural dialogue, even though the passage discusses communication in a shared mother tongue. Yet, most of the documents can be interpreted as calls for social responsibility because of their nature as recommendations, conventions, and charters addressing social and cultural issues of inclusion, human rights, and social justice.

In the following list, we summarize the core concepts included in the examination of intercultural dialogue in European education policy documents and the varying forms of other concepts, terms, and expressions used to discuss them in the data. The list indicates how these core concepts are interrelated and overlapping, and their variations are used flexibly and interchangeably. At the same time, the list reveals the conceptual vagueness and ambiguity in European education policies.

Intercultural dialogue: (plain) dialogue (as indicating dialogue between people with different cultural backgrounds); dialogue between cultures; 
interfaith dialogue; ability to hear and respect other viewpoints; intercultural communication; intercultural competences; intercultural skills; intercultural education; intercultural understanding; intercultural awareness; interculturalism; diversity management; cultural exchange; multilingualism; cooperation (between cultures or countries, or at the European level); cross-cultural understanding; cross-cultural learning skills; harmonious coexistence (of many languages)

Culture: cultural (defining cultural qualities of various issues)

Cultural heritage: heritage; shared inheritance; (our) common cultural background; heritage language; heritage culture; EU heritage; Europe's rich heritage; public and private heritage; architectural heritage; common (historical) heritage; shared ideals and principles; university heritage; academic heritage; shared heritage; cultural and linguistic heritage; a student's heritage

Identity: national identity; European identity; learner's individual and collective identities; cultural identity

Inclusion: integration; cohesion; understanding; recognition; admission; equality; (equal) access; approval; accession (in relation to working against discrimination); (as opposed to) exclusion; social cohesion; inclusive society; inclusive education; unity within diversity; respect (for others)

Empathy: respect (for others); mutual understanding; reconciliation; empathic; emotional care; solidarity (as a feeling towards others)

Tolerance: (as opposed to) intolerance; understanding diversity and difference; mutual respect; non-discrimination; mutual understanding; overcoming prejudice; openness

Multiculturalism: multicultural; multilingual; multilingualism; cultural diversity; cultures; pluricultural; diverse backgrounds; cross-cultural understanding; cross-border cooperation; European cooperation; interculturalism; plurilingualism; plurilingual

Citizenship: citizen; citizens; democratic citizenship

Participation: access; admission; democratic citizenship

Social responsibility: social inclusion; solidarity; mutual assistance; building cohesive societies; (active) participation; non-discrimination; equal opportunities; democratic citizenship; socially responsible; a sense of responsibility; responsibility as an individual citizen 


\section{REFERENCES}

Banús, E. 2015. Keynote Speech in 13th International Conference European Culture. Cluj-Napoca, Romania, October 29-31.

Barrett, M. 2013. Intercultural Competence: A Distinctive Hallmark of Interculturalism? In Interculturalism and Multiculturalism: Similarities and Differences, ed. M. Barrett, 147-168. Strasbourg: Council of Europe.

Cantle, T. 2013. Interculturalism as a New Narrative for the Era of Globalization and Super-diversity. In Interculturalism and Multiculturalism: Similarities and Differences, ed. M. Barrett, 69-92. Strasbourg: Council of Europe Publishing.

CofE (Council of Europe). 1954. European Cultural Convention. Paris, December 19. Strasbourg: Council of Europe.

- 1977. European Convention on the Legal Status of Migrant Workers. Strasbourg, November 24. Strasbourg: Council of Europe.

. 1997. The Lisbon Convention. Convention on the Recognition of Qualifications Concerning Higher Education in the European Region. Lisbon, April 11. Strasbourg: Council of Europe.

- 2000. Recommendation Rec(2000) 10 on the Codes of Conduct for Public Officials. Adopted by the Committee of Ministers at its 106th Session on 11 May 2000. Strasbourg: Council of Europe.

- 2001. Recommendation Rec(2001)15 on History Teaching in Twenty-Firstcentury Europe. Adopted by the Committee of Ministers on 31 October 2001 at the 771st Meeting of the Ministers' Deputies. Strasbourg: Council of Europe.

- 2008. Recommendation Rec(2008)4 on Strengthening the Integration of Children of Migrants and of Immigrant Background. Adopted by the Committee of Ministers on 20 February 2008 at the 7018th Meeting of the Ministers' Deputies. Strasbourg: Council of Europe.

- 2010. Council of Europe Charter on Education for Democratic Citizenship and Human Rights Education. Strasbourg: Council of Europe.

- 2011a. Recommendation Rec(2011)2 on Validating Migrants' Skills. Adopted by the Committee of Ministers on 19 January 2011 at the 1103rd Meeting of the Ministers' Deputies. Strasbourg: Council of Europe.

- 2011b. Recommendation Rec(2011)6 on Intercultural Dialogue and the Image of the Other in History Teaching. Adopted by the Committee of Ministers on 6 July 2011 at the 1118th meeting of the Ministers' Deputies. Strasbourg: Council of Europe.

- 2012a. Recommendation Rec(2012)13 on Ensuring Quality Education. Adopted by the Committee of Ministers on 12 December 2012 at the 1158th Meeting of the Ministers' Deputies. Strasbourg: Council of Europe.

- 2012b. Democracy and Human Rights Start with Us-Charter for All. Council of Europe Charter on Education for Democratic Citizenship and Human Rights Education: Guidelines for Educators. Ed. E. Diez Villagrasa. Strasbourg: Council of Europe. 
2014a. Recommendation Rec(2014) 5 on the Importance of Competences in the Language(s) of Schooling for Equity and Quality in Education and for Educational Success. Adopted by the Committee of Ministers on 2 April 2014 at the 7196th Meeting of the Ministers' Deputies. Strasbourg: Council of Europe.

- 2014b. Recommendation Rec(2014)7 on the Protection of Whistleblowers. Adopted by the Committee of Ministers on 30 April 2014 at the 7198th Meeting of the Ministers' Deputies. Strasbourg: Council of Europe.

- 2015. European Social Charter (Collected Texts, 7 th Edition): 1 January 2015. Strasbourg: Council of Europe.

- 2018. Children and Adolescents from a Migrant Background: Integration and Education. Extracts from Conventions, Recommendations, Resolutions and Reports. Revised and Enriched Version-April. Strasbourg: Council of Europe.

CofEC (Commission of the European Communities). 2005. Communication from the Commission to the Council, the European Parliament, the European Economic and Social Committee and the Committee of the Regions. COM(2005) 596 Final. A New Framework Strategy for Multilingualism. Brussels: Commission of the European Communities.

- 2008. Communication from the Commission to the European Parliament, the Council, the European Economic and Social Committee and the Committee of the Regions-Multilingualism: An Asset for Europe and a Shared Commitment. $\operatorname{COM}(2008) 566$ Final. Brussels: Commission of the European Communities.

CofEU \& EC (Council of the European Union \& the European Commission). 2015. Joint Report of the Council and the Commission on the Implementation of the Strategic Framework for European Cooperation in Education and Training (ET 2020): New Priorities for European Cooperation in Education and Training. Official Journal of the European Union C417: 25-35.

CofEU \& RofGofMS (Council of the European Union and the Representatives of the Governments of the Member States). 2008. Conclusions of the Council and of the Representatives of the Governments of the Member States, Meeting within the Council of 22 May 2008 on Promoting Creativity and Innovation Through Education and Training. Official Journal C141: 17-20.

- 2016. Resolution of the Council and of the Representatives of the Governments of the Member States, meeting within the Council, 24 February 2016 on Promoting Socioeconomic Development and Inclusiveness in the EU Through Education: The Contribution of Education and Training to the European Semester 2016. Official Journal of the European Union C105: 1-4.

CofEU (Council of the European Union). 2009a. Council Conclusions of 12 May 2009 on a Strategic Framework for European Cooperation in Education and Training ('ET 2020'). (2009/C 119/02). Official Journal of the European Union C1 19: 2-10. 
2009b. Council Conclusions of 26 November 2009 on the Education of Children with a Migrant Background. Official Journal of the European Union C301: 5-8.

2014. Council Conclusions of 21 May 2014 on Gender Equality in Sport. Official Journal of the European Union C183: 39-42.

- 2015a. Council Conclusions on Reinforcing Youth Work to Ensure Cohesive Societies. Official Journal of the European Union C170: 2-3.

- 2015b. Council Conclusions on the Role of Early Childhood Education and Primary Education in Fostering Creativity, Innovation and Digital Competence. Official Journal of the European Union C172: 17-21.

- 2015c. Council Conclusions on Reducing Early School Leaving and Promoting Success in School. Official Journal of the European Union C417: 36-40.

- 2016. Council Conclusions of 30 May 2016 on Developing Media Literacy and Critical Thinking Through Education and Training. Official Journal of the European Union C212: 5-8.

Cronin, A.M. 2002. Consumer Rights/Cultural Rights: A New Politics of European Belonging. European Journal of Cultural Studies 5 (3): 307-323.

De Leeuw, M., and S. van Wichelen. 2012. Civilizing Migrants: Integration, Culture and Citizenship. European Journal of Cultural Studies 15 (2): 195-210.

DIALLS. 2018. Cultural Analysis Framework. https://dialls2020.eu/wp-content/uploads/2019/09/resubmitted-cultural-analysis-framework-with-coversheet-.pdf.

EC (European Commission). 2010. Communication from the Commission to the European Parliament, the Council, the European Economic and Social Committee and the Committee of the Regions. A New Impetus for European Cooperation in Vocational Education and Training to Support the Europe 2020 Strategy. $\operatorname{COM}(2010) 296$ Final. Brussels: European Commission.

- 2017. Communication from the Commission to the European Parliament, the Council, the European Economic and Social Committee and the Committee of the Regions. School Development and Excellent Teaching for a Great Start in Life. $\operatorname{COM}(2017) 248$ final. Brussels: European Commission.

EP \& CofEU (European Parliament and the Council of the European Union). 2006. Recommendation of the European Parliament and of the Council of 18 December 2006 on Key Competences for Lifelong Learning, 2006/962/ EC. Official Journal of the European Union L394: 10-18.

. 2013. Regulation (EU) No 1288/2013 of the European Parliament and of the Council of 11 December 2013 Establishing 'Erasmust': the Union Programme for Education, Training, Youth and Sport and Repealing Decisions No 1719/2006/EC, No 1720/2006/EC and No 1298/2008/EC (Text with EEA Relevance). Official Journal of the European Union L347: 50-73. 
Ganesh, S., and P. Holmes. 2011. Positioning Intercultural Dialogue: Theories, Pragmatics, and an Agenda. Journal of International and Intercultural Communication 4 (2): 81-86.

Houghton, S.A. 2012. Intercultural Dialogue in Practice: Managing Value Judgement through Foreign Language Education. Bristol: Multilingual Matters.

Isac, M.M., A. Sandoval-Hernández, and D. Miranda. 2018a. Teaching Tolerance in a Globalized World: Final Remarks. In Teaching Tolerance in a Globalized World, ed. A. Sandoval-Hernández, M.M. Isac, and D. Miranda, 125-135. Berlin: Springer Open.

- 2018b. Teaching Tolerance in a Globalized World: An Introduction. In Teaching Tolerance in a Globalized World, ed. A. Sandoval-Hernández, M.M. Isac, and D. Miranda, 1-10. Berlin: Springer Open.

Jarausch, K.H. 2010. Nightmares or Daydreams? A Postscript on the Europeanisation of Memories. In A European Memory? Contested Histories and Politics of Remembrance, ed. M. Pakier and B. Stråth, 309-320. New York: Berghahn Books.

Jones, S., and J. Subotic. 2011. Fantasies of Power: Performing Europeanization on the European Periphery. European Journal of Cultural Studies 14 (5): 542-557.

Karlsson, K.-G. 2010. The Uses of History and the Third Wave of Europeanisation. In A European Memory? Contested Histories and Politics of Remembrance, ed. M. Pakier and B. Stråth, 38-55. New York: Berghahn Books.

Lähdesmäki, T. 2012. Rhetoric of Unity and Cultural Diversity in the Making of European Cultural Identity. International Journal of Cultural Policy 18 (1): 59-75.

- 2016a. Comparing Notions on European Cultural Heritage in EU Policy Discourse and Scholarly Discussion. The International Journal of Interdisciplinary Social Sciences: Annual Review 11 (1): 1-14.

- 2016b. Politics of Tangibility, Intangibility, and Place in the Making of European Cultural Heritage in EU Heritage Policy. International Journal of Heritage Studies 22 (10): 766-780.

Lentin, A., and G. Titley. 2012. The Crisis of 'Multiculturalism' in Europe: Mediated Minarets, Intolerable Subjects. European Journal of Cultural Studies 15 (2): 123-138.

Mutz, D.C. 2002. Cross-Cutting Social Networks: Testing Democratic Theory in Practice. American Political Science Review 96 (1): 111-126.

Näss, H.E. 2009. A New Agenda? The European Union and Cultural Policy. London: Alliance Publishing Trust.

- 2010. The Ambiguities of Intercultural Dialogue: Critical Perspectives on the European Union's New Agenda for Culture. Journal of Intercultural Communication 23: 1404-1634. https://www.immi.se/intercultural/ nr23/nass.htm. 
O'Callaghan, C. 2011. Urban Anxieties and Creative Tensions in the European Capital of Culture 2005: 'It Couldn't Just Be about Cork, Like. International Journal of Cultural Policy 18 (2): 185-204.

Rosamond, B. 2000. Theories of European Integration. Basingstoke: Palgrave.

Sassatelli, M. 2006. The Logic of Europeanizing Cultural Policy. In Transcultural Europe: Cultural Policy in a Changing Europe, ed. by U. H. Meinhof and A. Triandafyllidou, 24-42. Basingstoke: Palgrave MacMillan.

- 2009. Becoming Europeans. Cultural Identity and Cultural Policies. New York: Palgrave Macmillan.

Shore, C. 2006. 'In uno plures' (?) EU Cultural Policy and the Governance of Europe. Cultural Analysis 5: 7-26.

Sniderman, P.M., P.E. Tetlock, J.M. Glaser, D.P. Green, and M. Hout. 1989. Principled Tolerance and the American Mass Public. British Journal of Political Science 19 (1): 25-45.

Sullivan, J.L., J. Piereson, and G.E. Marcus. 1979. An Alternative Conceptualization of Political Tolerance: Illusory Increases, 1950s-1970s. American Political Science Review 73 (3): 781-794.

Troitino, D.R. 2013. European Integration: Building Europe. Hauppauge: Nova Science Publishers.

UNESCO. 1995. Declaration of Principles on Tolerance. Proclaimed and Signed by the Member States of the UNESCO on 16 November 1995. Paris: UNESCO.

Open Access This chapter is licensed under the terms of the Creative Commons Attribution 4.0 International License (http://creativecommons.org/licenses/ by $/ 4.0 /$ ), which permits use, sharing, adaptation, distribution and reproduction in any medium or format, as long as you give appropriate credit to the original author(s) and the source, provide a link to the Creative Commons licence and indicate if changes were made.

The images or other third party material in this chapter are included in the chapter's Creative Commons licence, unless indicated otherwise in a credit line to the material. If material is not included in the chapter's Creative Commons licence and your intended use is not permitted by statutory regulation or exceeds the permitted use, you will need to obtain permission directly from the copyright holder.

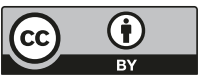

